ROAR, the University of East London Institutional Repository: http://roar.uel.ac.uk

This article is made available online in accordance with publisher policies. Please scroll down to view the document itself. Please refer to the repository record for this item and our policy information available from the repository home page for further information.

Author(s): Daniel Briggs

Title: Robbery careers: desistance attempts

Year of publication: 2008

Citation: Briggs, D., (2008), 'Robbery careers: desistance attempts', Safer

Communities, 7(3), pp. 37-34, DOI: 10.1108/17578043200800027.

Link to published version:

http://dx.doi.org/10.1108/17578043200800027

Publisher statement:

Information on how to cite items within roar@uel:

http://www.uel.ac.uk/roar/openaccess.htm\#Citing 


\title{
Robbery Careers and Desistance
}

\begin{abstract}
This paper presents four case studies of young people involved in street robbery. The paper analyses their street robbery 'careers', highlighting key pathways and turning points, into and out of street robbery and gang affiliation. The case studies are drawn from research undertaken by the author in a South East London borough in 2007.
\end{abstract}

\section{Key words:}

Robbery, Street Crime, Gangs, Young People, Drugs, Desistance

\section{I ntroduction}

Research suggests that the main motives for street robbery are the desire for high-status goods, designer clothes, drink and drugs (Fitzgerald et al., 2003), fun and excitement, a wish to settle scores with other young people and to enhance reputation and status (Smith, 2003; Sanders, 2004; Wright et al., 2006). As a result, these crimes are often portrayed simply as a product of rational calculation (Wright and Decker, 1994; Horvath and Kolomaznikova, 2002; Topalli, 2005), but this ignores the importance of 'social context' in the decision to become involved in, or desist from, street crime (Farrall and Bowling, 1999). Indeed, most research into desistance considers that the social context is crucial to 'transitions and desistance pathways' into and out of crime (Bottoms et al., 2004). Desistance studies generally recognise that desistance from crime is not an event but a process (Cromwell et al., 1991; Maruna, 2001; Bottoms et al., 2004) whereby skills, accumulated over time, enhance the offender's capacity to avoid recidivism (Laub and Sampson, 2001).

Motivations for street robbery are complex; routes into street robbery are often surprising and routes out are often temporary and unpredictable. The article considers how street robbery careers unfold and how they are shaped by individual circumstance and social context. 


\section{Methodology}

Concern about young black men's overrepresentation in street robbery offences provided the impetus for the work in a South East London borough. Over three months, 40 young black men ( 20 offenders and 20 vulnerable to involvement in street crime) were interviewed in pubs, cafes, streets, parks, and in the Youth Offending Team (YOT) offices. The interviews were semi-structured and explored young people's involvement in street robbery, their knowledge of, and involvement in, gangs, their experience of mainstream services and their thoughts about the effectiveness, or otherwise, of the interventions to which they had been subject.

\section{The Findings}

\section{Staving Off the Pressure: Kam's Story}

Kam approached me smiling. He said "you're not the feds, so here I am, but don't be shopping me bruv". Kam, who would "not back down to a fight or a robbery", was sixteen and still in school. Making money had always been a priority for Kam. His father died when he was young and he had had to be 'self sufficient' from an early age. He spoke of his early days, "making money" at primary school by "lifting from Woolworths" and selling on the higher-priced proceeds to "other kids who weren't allowed to buy this shit."

He recalled seeing "people get robbed in [secondary] school" at the age of eleven. Indeed, his first experience of victimisation, in year seven, was when an "older guy robbed his mobile". These early experiences made him want to retaliate in kind. Aged twelve, he took to robbing members of the public "early in mornings on buses" and on "trains when people were asleep" because it was the "best way to do it because of no confrontation". The proceeds were spent on supporting his family and an increasingly appealing lifestyle of "new clothes and weed".

By the age of fourteen, he spent time in a secure unit for a gang robbery in which someone was stabbed. He says "wised up inside" and "moved away from it [robbing members of the public]". Reflecting on the dangers of group robberies, he said:

"I know that if there are four of us, the situation could be unpredictable because one guy will want to get violent and I wouldn't want that to happen and I get caught for some serious shit like GBH. Then again some people carry shanks so that is in the mix so you can't tell what's going to happen, bruv. Some people I know, I seen how they rob people and I don't like it so I tell them. They don't listen but at least I tried." 
The pressure to fund himself and his family did not go away and so, on release, he took an 'off the books' labouring job on a building site, while still attending school intermittently. Despite being under the supervision of the YOT, he twice worked with members of his "crew" robbing people at ATMs. At the age of fifteen, his "crew" moved into armed robbery and he was involved as "back up for numbers" in a post office robbery. The proceeds, $£ 15,000$, were shared between his four "cousins". Although the police pulled him in as a suspect, he was never charged.

Life in a gang or crew can be very violent and, as a result of a number of "beefs" [vendettas], he was "stabbed four times". In consequence, he began to revaluate his position in the gang and he "backed away from the frontline" so that he "could go everywhere" without fear. However, he felt he had to remain loyal to his "crew" and so kept himself available to them just in case "the call was made". In May 2006 because, having desisted from street robbery, he said he felt "hungry for the money.", and considered "robbing drug dealers": "if someone is selling and you know they have sum but you don't want to buy, you run up with two other mans, two bigger guys, and you split the cash and you can make hundreds in a day." In fact, having contemplated it, he decided not to do it.

Instead, and somewhat reluctantly, because of the stigma attached to such "low status" work amongst his peers, he tried to get work in fast-food restaurants and retail outlets. However, he Was unsuccessful because of his age and criminal convictions. Meanwhile, most of his friends were earning "good money" "shotting" [drug dealing]. He began to think that if he "let himself down at college" shotting may be "the only way."

It was around this time that he served a brief sentence in a Young Offender Institution (YOI) for five breaches of his supervision order. On his release, in September 2006, he had two, two-week, stints of drug dealing to make some money quickly. Nonetheless, having done so, once again he desisted from crime although the temptation and the opportunity was always there.

"I was going to start shotting the other day but I backed out. Proper whites [crack], browns [heroin], you earn g's [thousands], yeah. I know someone or someone knows someone, it is all connected, we are all connected in some way...Like I got out in September and tried to keep my head down, init but times are difficult and my mum has got nothing. I am thinking about it. You can't escape it." 
In the four years he was involved, Kam estimated that he and his crew had done 30 robberies but he had been caught and convicted for only two. Despite having desisted, he is still close to his crew, having known them since secondary school, and he is still au fait with what they are up to. Although he is no longer on the "frontline" the temptations of easy money are ever-present, and exacerbated by his lack of academic qualifications, accredited training, a criminal record and the need to support himself and his family.

\section{Blurred Perceptions of the Future: Shadow's Plans}

We first met in McDonalds. Shadow, the oldest in a family of four with no father, was sixteen, and at school, hoping to go on to college. Like many of his peers, he aimed "to finish school without being in too much trouble with the police". However, the likelihood of this being so was diminished by his persistent drug dealing. His first experience of crime was in secondary school. He started his robbery career to support his mother but soon became aware of its additional benefits:

"I used to do it day in day out back in the day. There has been time when mans had no electricity, so when I'm out on road, I am out getting money for us to survive. We had cold water unless I went out every day. I used to go out by mans self, go out in the morning and have straight $f 50-60$ per day, every day, phones, mp3, munch, weed, everything and all from robberies. True stories"

He would target "the posh boys" who were "kitted out good". On one occasion, he was "outside one school" and robbed seven boys at once by himself: "they got no road skills and mummy and daddy pay them nice". Drawn into the lifestyle and increasingly losing contact with school, he spent more time "on the streets, jamming ends". Gradually, his robbery targets shifted from other schoolboys to members of the public. Realising that there was more money to be made at nights, his focus switched to intimidating night attacks on "businessmen [with] nice phones and laptops". He then moved on once again to robbing older gang-affiliated men, to "gain rep" among gang 'Olders'.

He continued to undertake his robberies "on his ones" because "other boys got too greedy". Increasingly, however, he was confronted with hostile gangs and endured a number of beatings and attempted robberies. By the age of fifteen, he had accrued five outstanding arrest warrants for street robbery. One evening he was involved in a car crash which hospitalised him and killed a member of his "crew". He handed himself in to the police, "took two charges 
and three were dropped." In court he was placed on an Intensive Supervision and Surveillance Order (ISSP) for six months:

"It was kind of boring [the YOT] but it was alright. They were supposed to keep my focus but I don't really see how. It was more of a ting of keeping man in order. Whatever they told me, I already knew. They need to go past that. They don't needed to ask me why am I doing this shit."

These six months proved to be decisive. His involvement with local gangs was drastically reduced as was his involvement in street robbery. The reason, he said, was because "man had been through some life-threatening shit". He did not desist from crime, however, he diversified. Using his well-established networks, he moved into cannabis dealing and returned to school. However, the need to support himself and his family was still there, as was the temptation of seeing his "Olders rolling in nice cars". He needed money:

" $£ 10$ can not last me an hour now, bruv. The way it is, man is getting older, man's needs are becoming more defined and man needs to start earning serious money. You have to learn quick because you can't keep robbing all your life."

Although now involved in dealing cannabis and crack, if he was "hungry enough" and if the "other things" did not reap money "quick", he reasoned that he may "still rob". Nonetheless, he remained positive about his future in a legitimate sphere:

[In one year] "Hopefully have a job and in college doing bigger things, be more legit. Man is going to take advantage of both sides, man is going to take advantage of the system. I will hold down a job and do my ting." [In five years I will have] "safe job off road but not out of it. I will be shifting the shit [drugs], smoking my big blunt. I will be a big man by then. All I am saying that I know it was hard for me so I am gonna be looking after my brothers and Youngers because someone looked after me. Man had nothing but man took me under wing. So I will be starting niggas off who have nothing so they can have something. Man can't forget where he is from."

Although the car crash and the YOT intervention had an impact upon his street robbery career, it also inadvertently laid the foundations for his current position. Now with 'new needs' and an increasing appetite for a lifestyle centred the 'streets' and amongst peers, Shadow moved into drug dealing. Depending on his academic success, or otherwise, and providing that he can maintain his 
anonymity, Shadow could well rise to the top of the local drugdealing hierarchy.

\section{New Father, New Family: The Stacker's Dilemma}

The Stacker appeared in a blue baseball cap. The tall, lean nineteen-year old, was the most polite and placid crack dealer I have met. He pressed me to record the conversation: "Stupid people do it [street robbery] for a rep as a gangsta, other people do it for the money, or to get shotters who sell drugs". His early experiences of robbery were in the context of victimisation, although when he was eight he was quite curious about why his older brothers had "nice cameras and things":

"I was a good kid, mum and dad taught me well; up until first time was robbed aged twelve. They took my bike, my chain, knocked me out cold and after that I didn't want it to happen again. It is not about families, my family don't know about my robberies, stabbings or shootings. It is like everyone, when you are outside you are in a different world. It is about getting one up on everyone and it is like that your whole life."

Having avoided any criminal convictions and prison, he counted himself lucky to have "been arrested a few times", but he "never meant" to get into robbery: in fact it was, "while with a friend", when he was fifteen, that he first became involved. He said that his involvement in street robbery had been "accidental", becoming a "part time ting for the money". He was aware, however, of the need for caution because "cops were there, quick" and because repercussions were "a big thing on the streets". He developed a reputation for his "cool head" and became part of a local gang as a 'Younger'. This was, in part, because his older brothers had followed a similar path within the same gang and his name was already attributed to them.

By the age of seventeen, after a relatively short period robbing other young people and members of the public, he moved into drug dealing having seen how much money a friend who was "shotting": was making.

"I saw him getting money, car, trainers and I thought 'I want a piece of that'. He set me up selling quarters at first, then ounces. People move up once they realise there is nothing in street robberies, when there is more in armed robberies and drug dealing."

Stacker's arrest for possession of a gun did little to deter him from his chosen path; even less so when the police lost the evidence. His 
involvement with gangs increased, he became an 'Older' and his expectations "become solid". However, life started to become more complex as he turned eighteen. His parents were becoming suspicious about his newfound wealth and so he registered with a theatrical 'extras' agency in order to present a legitimate facade and, possibly, to generate some legitimate income.

And then, just before his nineteenth birthday, his girlfriend became pregnant and this caused him to reflect on the life he was living and whether this was what he wanted for his new family. Soon afterwards, his best friend was shot after robbing a dealer and his family's house was the target of "warning gunshots". He said:

"I am at a point in my life where there is so much money to be made out there, it is just I don't really want to, it is dangerous, I have seen guns, all weapons, all that shit. When I became a shotter, it was easy money. $£ 800$ a week. Now I don't know what to do."

Having attained five GCSEs, but having dropped out of college, he was reluctant to "start again" and lacked the "confidence" to get legitimate work. Indeed, his perception of the available educational and vocational opportunities was very negative:

“Education ain't the way, I advise to everyone Younger. If I am sitting at home waiting for it, like you are trying to get a job, trying to get work, your parents are like "why don't you get a job?" and you can't because you have tried so you have to make money. If you can, it is a dream. No one wants to do this but it is the choices that are around for people. When you can't make legit money, you have to make some kind of money. Job seekers ain't gonna see you through."

Stacker believed that either a "realisation" or "serious injury" would cause him to desist from street robbery or drug dealing, although probably the latter. His lack of confidence in his ability to 'start again' and the financial pressures of a young family, mean that despite his expressed desire 'to get out', he was fatalistic about his predicament, which he summarised thus: "[in a year or two] I may not be here, probably dead, selling drugs or inside".

\section{Hustler's New Ambitions}

He was quite happy to talk in the café opposite the YOT. With 11 GCSE's and a "safe upbringing", 18-year old Hustler said the his "stupid mistakes" had a lot to do with "... the area you are brought up in...quite a lot of people go with their environment more than anything else". He had always lived with his mother and two older 
brothers, and crime had always been part of his older brothers' lives:

"When I was a kid and they had a lot of friends who sold drugs and they were round my house, and I went out with them sometimes and I saw them do things, I see them robbing people, selling drugs, see them making a lot of money. I was like five, me and my brothers are very close"

He had ended up dealing crack cocaine, starting at the age of fifteen and stopping when he was eighteen. He recalled how he "drifted into this path" at secondary school. He said he "did not have the heart" to rob people. He said that for some, street robbery was because they "can't get jobs", while others "were greedy" and others were just "influenced by the streets". He saw "two roads"; street robbery or drug dealing:

“I haven't robbed yeah, well I...I have robbed yeah, but not people, drug dealers, people who have not worked hard for it. I wouldn't rob people who have a legit job, who have worked hard for their selves. Like drug dealers are a different circles, they deserve it. I see it they have not worked hard."

Over the last two years, he had done "fifteen or so" drug dealer robberies, selling the proceeds on to "other parties". He reasoned that this was a "safe bet" because drug dealers would not "report to the police". In this period he had been "sliced down his back". He said that "on the streets anything could happen, anytime so not a new thing. I'm not surprised if people shot or shanked. You can't go through the street life without being stabbed or beaten. Something will eventually happen to you". He explained that:

"I was rolling with my crew and we got robbed by another crew, which made me want to rob them and do something worse [Dan: why?] It went to a different level, it turned into a fight so I went to fight and shanked this boy and he came back twice as hard with a knife and done me."

This, he said, was to avoid looking like a "dickhead" in front of his peers. However, on the way to one of his "jobs", he was "pulled by the feds" and arrested for possession of drugs and driving with no licence. In court he received a supervision order. This experience had an impact on him because it was his first "run in" with the law:

"It has made me wiser, going through the process. If I was to go back to selling drugs I would be wiser than before, I would 
think differently and what I am doing. Is it worth it and would I get away with it?"

Although, at first, he was "frustrated with YOT" because he didn't enjoy the activities, it made him a "better person" because he appreciated "life away from the streets". He said he just wanted "out of it", "to get a job" and felt he "could drop dealing" because he had "made a lot of money from drugs". This said, he also recognised that would be difficult to "go down in life", "starting again in retail", earning "five bills [hundred pounds] a month". He was also concerned about the repercussions of earlier activities catching up with him:

“Once get into street life, hard to get out. Once you done so many things to so many people, it could be ten years down the line you have your job, your kids but you see that one person you did something to and they want revenge on you for what you did to them. It is hard to come out of the game because you can't escape the consequences one way or another."

His brothers were also now advising him to "take the legit road" since he had only one conviction and he was returning to college. In comparison with Kam, Shadow and Stacker, Hustler appears to have made 'a lucky escape', with only a meagre criminal record and a college place. However, time will be the test of whether he can resist the temptations of the streets and his companions who are still making 'good money' on them.

\section{Discussion}

Too often, the motivations for robbery are depicted as 'stand alone' factors which fail to do justice to the complexities of the predicament of these young people. Getting into, or out of, robbery is less an 'event' and more a process that unfolds over time (Sampson and Laub, 1993). The determining factors may be pressure to maintain a family; the social pressures of 'street culture'; the need to maintain 'rep' and respect among peers, not least because this will serve to protect you from attack, and a general disillusionment with mainstream institutions and their capacity to provide a viable future. Street robbery careers are crucially shaped by these, and a multiplicity of other contextual factors.

It is evident that, because of the social networks developed early in life, involvement in street crime and drug dealing remains an everpresent option for those endeavouring to desist. Robbery careers develop and change over time, from robbing other schoolchildren, 
to robbing members of the public, to robbing rival gangs and, eventually, to robbing drug dealers. In each of these four cases we see the young men becoming ever more deeply embroiled in street culture and gang affiliation.

Desistance is never clear-cut. Temporary desistance may occur following an arrest, a new relationships, the intervention of a youth serving or criminal justice agency, serious injury to one's self, or the injury or death of a close friend. Bottoms et al. (2004) have said:
"A person's overall movement may be towards desistance, but each week or month may see further episodes of criminality, possibly of different types, as opportunities present themselves, daily living pressures cannot be staved off, or social encounters occur. All of these, we think, are in interaction with people's own views of themselves (self- identity) and of their place amongst those they know and those living in that society (social identities)."

(Bottoms el al., 2004: 383)

\begin{abstract}
Desistance is therefore contextual and contingent. Often these 'crossroad' decisions are skewed by the ease with which money can be made illegally, and this contrasts starkly with, the lack of capital, credibility and 'rep' yielded by the low-paid jobs, for which they have requisite experience and qualifications (Collinson, 1996). This lack of status-conferring legitimate opportunity, combined with disillusionment with mainstream institutions, and the prospect of 'starting again' at the 'bottom of the ladder', serves as a powerful disincentive to desistance. For the professionals involved with them, the challenge is to ensure that as they are closing the door on their past criminality, we are enabling them to open up another which leads to plausible legitimate opportunities.
\end{abstract}

\title{
References
}

Bottoms, A., Shapland, J., Costello, A., Holmes, D., and Mair, G. (2004) 'Towards Desistance: Theoretical Underpinnings for an Empirical Study ' in The Howard J ournal of Criminal J ustice 43 (4): 368-89.

Collinson, M. (1996) 'In search of the high life: drugs, crime, masculinity, and consumption.' in British J ournal of Criminology, $36,3,428-44$.

Cromwell, P., J. Olson, and Avary, D. (1991). Breaking and Entering: An Ethnographic Analysis of Burglary. Newbury Park, CA: Sage. 
Farrall, S., and Bowling, B. (1999) 'Structuration, human development and desistance from crime' in British journal of Criminology, Volume 39: number 2, 253-268.

Horvath, R., and Kolomaznikova, E. (2002) 'Individual decisionmaking to commit a crime: Early models' in Law and Economics, 0210001, EconWPA

Laub, J., and Sampson, R. (2001) 'Understanding Desistance from Crime ' in Tonry, M.H. and Morris, N. (Eds) Crime and J ustice: An Annual Review of Research Vol.26, pp.1-78, University of Chicago Press, Chicago.

Maruna, S. (2001) Making Good: How Ex-Convicts Reform and Rebuild their Lives. American Psychological Association Books, Washington DC.

Sampson, R., and Laub, J. (1993) Crime in the Making: Pathways and Turning Points Through Life, Harvard University Press: London.

Sanders W. (2004) Gang Culture and Street Crime in a London Neighbourhood, Unpublished PhD Thesis.

Smith, J. (2003) The Nature of Personal Robbery, London: Home Office Research Study 254.

Topalli, V. (2005) 'Criminal Expertise and Offender Decision-Making: An Experimental Analysis of How Offenders and Non-Offenders Differentially Perceive Social Stimuli' in The British J ournal of Criminology, Vol. 45, Issue 3, pp. 269-295.

Wright, R., and Decker, S. (1994) Burglars on the job, Boston: Northeastern University Press.

Wright, R., Brookman, F., and Bennett, T. (2006) 'The Foreground Dynamics of Street Robbery in the UK' in The British Journal of Criminology, Vol. 46: 1-15. 